\title{
Five new species of the Botryosphaeriaceae from Acacia karroo
}

\section{in South Africa}

\author{
F. Jami ${ }^{1}$, B. Slippers ${ }^{2}$, M.J. Wingfield ${ }^{1}$, M. Gryzenhout ${ }^{3,4}$ \\ ${ }^{1}$ Department of Microbiology and Plant Pathology, ${ }^{2}$ Department of Genetics, Forestry \& \\ Agricultural Biotechnology Institute, University of Pretoria, Pretoria, South Africa; ${ }^{3}$ Department of \\ Plant Sciences, University of the Free State, Bloemfontein, South Africa, \\ ${ }^{1}$ E-mail: fahimeh.jami@fabi.up.ac.za (for correspondence)
}

\begin{abstract}
The Botryosphaeriaceae represents an important, cosmopolitan family of latent pathogens infecting woody plants. Recent studies on native trees in southern Africa have revealed an extensive diversity of species of Botryosphaeriaceae, about half of which have not been previously described. This study adds to this growing body of knowledge, by discovering five new species of the Botryosphaeriaceae on Acacia karroo, a commonly occurring native tree in southern Africa. These species were isolated from both healthy and diseased tissues, suggesting they could be latent pathogens. The isolates were characterized based on their morphology and compared to other species for which DNA sequence data are available, in phylogenetic analyses based on the ITS, TEF-1 $\alpha, \beta$-tubulin and LSU gene regions. The five new species were described as Diplodia allocellula, Dothiorella dulcispinae, Do. brevicollis, Spencermartinsia pretoriensis and Tiarosporella urbis-rosarum. Evidence emerging from this study suggests that many more species of the Botryosphaeriaceae remain to be discovered in the southern Africa.
\end{abstract}

\section{Acacia karroo/ Diplodia/ Dothiorella/ phylogeny/ southern Africa/ Tiarosporella/ Spencermartinsia/ taxonomy}

\section{INTRODUCTION}

The Botryosphaeriaceae (Dothideales) is a cosmopolitan family of fungi with a very wide host range of mostly woody plants. They can be primary or opportunistic pathogens, endophytes or saprobes, as reviewed by Slippers \& Wingfield (2007). Many species have been reported from South Africa in recent years, isolated from trees in the Myrtaceae (Eucalyptus spp.), Proteaceae (Protea spp.), Fabaceae (Acacia spp.), Combretaceae (Terminalia spp.) and Pinaceae (Pinus spp.) (Begoude et al., 
2010; Denman et al., 2003; Pavlic et al., 2004; Roux \& Wingfield, 1997; Slippers et al., 2004; Smith et al., 2001; Smith et al., 1994; Swart \& Wingfield, 1991; Van der Walt et al., 2008). Most studies on members of the Botryosphaeriaceae in southern Africa have focused on their association with trees of agricultural or forestry importance.

A few recent studies of Botryosphaeriaceae on native southern African trees, such as Syzygium cordatum (Myrtaceae), Pterocarpus angolensis (Leguminosae), Terminalia catappa (Combretaceae), Acacia spp. especially A. melifera (Fabaceae), and woody species of Leucadendron, Leucospermum and Protea (Proteaceae), have revealed large numbers of species in these native environments, many of which have represented new species and genera. In total, 32 species of Botryosphaeriaceae have been identified from native woody hosts in South Africa, 12 species of which have been from native African Acacia spp., eight species from $S$. cordatum, seven species from $P$. angolensis and five species from T. catappa. Among these 32 species, 15 were new taxa (Begoude et al., 2010; Mehl et al., 2011; Pavlic et al., 2007; Van der Walt et al., 2008). The number and distribution of new species in these studies suggest that there probably are many more Botryosphaeriaceae species in South Africa on unsampled hosts and in unexplored regions.

The ecological relevance of this diversity of the Botryosphaeriaceae discovered recently in native environments of South Africa, is not well understood. Endophytism is common to most species of the family. For example Diplodia pterocarpi Cooke, Lasiodiplodia crassispora T. Burgess \& Barber, L. mahajangana Begoude, Jol. Roux, Slippers, L. pseudotheobromae A.J.L. Phillips, A. Alves \& Crous, Neofusicoccum kwambonambiense Pavlic, Slippers \& M.J. Wingf., N. parvum (Pennycook \& Samuels) Crous, Slippers \& A.J.L. Phillips, N. batangarum Begoude, Jol. Roux \& Slippers, and Pseudofusicoccum olivaceum J.W.M. Mehl \& B. Slippers have been isolated from asymptomatic tissues of T. catappa in South Africa (Begoude et al., 2010). Many of the Botryosphaeriaceae are, however, best described as latent pathogens that can cause significant damage to woody agricultural crops and forestry species typically when host plants are under stress (Slippers \& Wingfield, 2007). This is also evident from their association with die-back of native trees such as those from S. cordatum in South Africa (Pavlic et al., 2004), namely Botryosphaeria dothidea (Moug. ex Fr.) Ces. \& De Not., L. gonubiensis Pavlic, Slippers \& M.J. Wingf., L. 
theobromae (Pat.) Griffon \& Maubl., N. australe (Slippers, Crous \& M.J. Wingf.) Crous, Slippers \& A.J.L. Phillips, N. luteum (Pennycook \& Samuels) Crous, Slippers \& A.J.L. Phillips, N. mangiferae (Syd. \& P. Syd.) Crous, Slippers \& A.J.L. Phillips, N. parvum (Pennycook \& Samuels) Crous, Slippers \& A.J.L. Phillips and N. ribis (Slippers, Crous \& M.J. Wingf.) Crous, Slippers \& A.J.L. Phillips. Pathogenicity studies with species of Botryosphaeriaceae have shown that they often differ in pathogenicity on a particular host, or between hosts. For example, N. vitifusiforme causes die-back on Vitis vinifera (Van Niekerk et al., 2004), but was isolated as an endophyte from healthy tissue of Terminalia spp. in southern Africa (Begoude et al., 2011). L. pseudotheobromae was isolated from both healthy tissues and those with symptoms of die-back on T. catappa trees, but isolates showed varying levels of pathogenicity on that host (Begoude et al., 2010). These studies have shown that much work will be required to fully understand the ecology of the Botryosphaeriaceae.

Little is known regarding species of the Botryosphaeriaceae on Acacia karroo in South Africa. This tree species is the most widespread and ecologically important native Acacia in southern Africa (Barnes et al., 1996; Timberlake et al., 1999). Previous studies on Botryosphaeriaceae species of native Acacia have focused mostly on A. mellifera (black thorn) and were limited to the Prieska area (Northern Cape province) in South Africa and Namibia (Van der Walt et al., 2008). Furthermore, surveys on non-native $A$. mearnsii or black wattle were conducted in Pietermaritzburg (KwaZulu/Natal Province), Piet Retief (Mpumalanga Province) and Alexandria (Eastern Cape Province) (Roux \& Wingfield, 1997; Roux et al., 1997). Samples of $A$. karroo were limited and yielded only three Botryosphaeriaceae species, namely $B$. dothidea, and a new species in Phaeobotryon and Spencermartinsia, respectively (Van der Walt et al., 2008). There thus appears to be substantial scope to more thoroughly sample this important and widespread host, especially in previously unsampled areas.

This study is part of a larger effort to document the diversity of the Botryosphaeriaceae associated with South African native trees in general, and on $A$. karroo in particular. Here we report on two previously unsampled regions of its distribution, namely Pretoria (Gauteng Province) and Bloemfontein (Free State Province) in South Africa. As in previous studies on native hosts, surveys revealed a 
high level of diversity of new Botryosphaeriaceae species. The isolated species were characterized here based on morphology and DNA sequences of the ITS, TEF1- $\alpha, \beta$ tubulin and large subunit rDNA gene regions.

\section{MATERIALS AND METHODS}

\section{Isolates examined}

Sixty four asymptomatic branches and 40 branches showing die-back were collected from 48 trees at various sites around the city of Pretoria, Gauteng Province, and from the Glen area, Bloemfontein, Free State Province, South Africa, in June 2008 and February 2010 (Table 1). Plant tissues were surface sterilized in $10 \%$ hydrogen peroxide for two minutes, rinsed three times in sterile water and placed on 2 $\%$ malt extract agar (Biolab, Midrand, South Africa). Cultures showing typical morphology of the Botryosphaeriaceae (fast growing, white to black cultures with aerial hyphae) were isolated after 4-5 days. Single hyphal-tip cultures of these isolates were made and these are maintained in the Culture Collection (CMW) of the Forestry and Agricultural Biotechnology Institute (FABI), University of Pretoria, Pretoria, South Africa, with duplicates of type cultures deposited in the Centraalbureau voor Schimmelcultures (CBS), The Netherlands.

\section{DNA sequence analyses}

Isolates obtained in this study were initially grouped based on culture morphology. DNA was extracted from the mycelium of 5-day-old single hyphal-tip cultures (Lee \& Taylor, 1990) of three representatives for each morphological group. Sequence data from the following genome regions were used in phylogenetic analyses, namely the internal transcribed spacer (ITS) region of the ribosomal RNA (rRNA) operon using primers ITS-1 (Gardes \& Bruns, 1993) and ITS-4 (White et al., 1990), the translation elongation factor $1-\alpha$ (TEF-1 $\alpha)$ gene using primers EF1-728F and EF1-986R (Carbon \& Kohn, 1999), the $\beta$-tubulin gene using primers Bt2a and Bt2b (Glass \& Donaldson, 1995), and the large subunit rDNA (LSU) gene region using primers LR0 and LR5 (Vilgalys \& Hester, 1990).

The $25 \mu 1$ PCR reaction mixtures contained $2.5 \mu 1$ of $10 \mathrm{mM}$ PCR buffer (PCR buffer with $\mathrm{MgCl}_{2}$ ), $1 \mu \mathrm{l}$ of $25 \mathrm{mM} \mathrm{MgCl}_{2}, 2.5 \mu \mathrm{l}$ of $100 \mathrm{mM}$ of each deoxynucleotide triphosphate, $1 \mu \mathrm{l}$ of $10 \mathrm{nM}$ of each primer, $2 \mathrm{ng}$ DNA template and 
1 U Taq polymerase (Biotech International, Needville, TX, USA). Non-template controls of sterile water were used with every PCR reaction. The amplification conditions were as follows: initial denaturation of $5 \mathrm{~min}$ at $95{ }^{\circ} \mathrm{C}$, followed by 35 cycles of 30 seconds at $95{ }^{\circ} \mathrm{C}, 30$ seconds at $56^{\circ} \mathrm{C}$, and 1 min at $72{ }^{\circ} \mathrm{C}$, and a final extension of $5 \mathrm{~min}$ at $72{ }^{\circ} \mathrm{C}$. Five $\mu \mathrm{l}$ of each PCR product were separated by electrophoresis in $1 \%$ agarose gels in $5 \%$ TAE buffer $(40 \mathrm{mM}$ Tris, $40 \mathrm{mM}$ acetate, 2 mM EDTA, pH 8.0). The amplified PCR fragments were purified with Sephadex (Sigma, Steinheim, Germany) and sequenced with the BigDye terminator cycle sequencing kit (Perkin-Elmer Applied Biosystems, Foster City, California, USA) in both directions, with the same primers used for the PCR reactions. Products were separated with an ABI 373048 capillary sequencer (Perkin-Elmer Applied Biosystems).

Sequences of the isolates were edited using Vector NTI 11 (Lu \& Moriyama, 2004). DNA sequences for species previously published were retrieved from GenBank (http://www.ncbi.nlm.gov). The resulting data matrices for each gene were rooted with Pseudofusicoccum stromaticum (Mohali, Slippers \& M.J. Wingf.) Mohali, Slippers \& M.J. Wingf. following the example of Phillips et al. (2008). The data matrices were aligned online using MAFFT (http://align.bmr.kyushuu.ac.jp/mafft/online/server/) version 6 (Katoh et al., 2005) and checked manually for alignment errors.

Phylogenetic analyses of sequence data for Maximum Parsimony (MP) and Maximum Likelihood (ML) were made using PAUP* v.4.0b10 (Swofford, 2001). Maximum parsimony (MP) genealogies for single genes were constructed with the heuristic search option (100 random taxa additions, tree bisection and reconstruction (TBR) in PAUP. The uninformative aligned regions within each dataset were removed from the analyses, gaps were treated as fifth character and all characters were unordered and of equal weight. Branches of zero length were collapsed and all multiple, equally parsimonious trees were saved. The robustness of the tree(s) obtained was evaluated by 1000 bootstrap replications. Congruence between the different datasets was tested using the partition homogeneity test (PHT) in PAUP (Phylogenetic Analysis Using Parsimony) version 4.0b10 (Farris et al., 1995; Huelsenbeck et al., 1996), with the uninformative characters removed before analysis. Other measures such as tree length (TL), consistency index (CI), rescaled consistency 
index (RC), and the retention index (RI) (Hillis and Huelsenbeck, 1992) were recorded.

For ML analyses, the best nucleotide substitution models for each dataset separately, were found with Modeltest 3.7 (Posada \& Buckley, 2004). The models $\mathrm{K} 81 \mathrm{uf}+\mathrm{I}+\mathrm{G} \quad(\mathrm{G}=0.528, \quad \mathrm{I}=0.476), \quad \operatorname{TrNef}+\mathrm{I}+\mathrm{G} \quad(\mathrm{G}=0.819, \quad \mathrm{I}=0.759), \quad \operatorname{Tr} \mathrm{N}+\mathrm{I}+\mathrm{G}$ $(\mathrm{G}=1.807, \mathrm{I}=0.144), \operatorname{TrN}+\mathrm{I}+\mathrm{G}(\mathrm{G}=1.476, \mathrm{I}=0.562)$ and $\mathrm{GTR}+\mathrm{I}+\mathrm{G}(\mathrm{G}=0.2910, \mathrm{I}=0.0)$ were chosen for the ITS, LSU, TEF-1 $\alpha, \beta$-tubulin and combined datasets, respectively. The analyses were also performed in PAUP $4.0 \mathrm{~b} 10$ and confidence levels were determined with 1000 bootstrap replications.

\section{Morphological characteristics}

To induce sporulation, cultures were inoculated onto sterilized twigs of $A$. karroo placed on the surface of $2 \%$ MEA (Biolab), and these were incubated at $25{ }^{\circ} \mathrm{C}$ under near-UV light. Fifty released conidia, and 20 pycnidia and conidiogenous cells were measured for the isolates chosen to represent holotypes for each putative new species, and the ranges and averages were computed. These measurements were augmented with 20 measurements obtained from additional isolates. Measurements and digital images were made with an HRc Axiocam digital camera and accompanying Axiovision 3.1 software (Carl Zeiss Ltd., Munich, Germany). The

specimens were deposited in the National Collection of Fungi (PREM), Pretoria, South Africa.

Colony morphology and colour were determined from cultures grown on MEA at $5-35{ }^{\circ} \mathrm{C}$, at $5{ }^{\circ} \mathrm{C}$ intervals, in the dark. For these, $6 \mathrm{~mm}$ diam. mycelial plugs were taken from the edges of actively growing 5-day-old single conidial cultures, and transferred to the centers of $25 \mathrm{ml} \mathrm{MEA}$ in $90 \mathrm{~mm}$ diam. Petri dishes. Three replicate plates were used for each isolate per temperature. Two perpendicular measurements were taken of the colony diameter daily until the mycelium of the fastest growing isolates had covered the plates and averages were computed. Colony colours were assigned using the designations of Rayner (1970).

\section{RESULTS}

\section{Isolates}


Several known as well as previously uncharacterized species of Botryosphaeriaceae were recovered from both healthy and diseased A. karroo and the focus of this study will only be on those not previously described. Twenty three isolates from all those recovered were determined as belonging to one of several new species. Six isolates of undescribed species were from samples collected in Bloemfontein and 17 were from the Pretoria area. These could be grouped into five morphotypes that were selected for sequencing.

\section{DNA sequence analyses}

The datasets for the ITS, TEF- $1 \alpha, \beta$-tubulin and LSU rDNA sequences were analyzed individually and in combination. The ITS sequence dataset contained 522 characters (4 parsimony-uninformative, 148 parsimony-informative, 370 constant characters) with $\mathrm{CI}=0.602, \mathrm{RI}=0.902, \mathrm{RC}=0.543, \mathrm{HI}=0.398$ and $\mathrm{TL}=321$. The TEF-1 $\alpha$ dataset contained 362 characters (3 parsimony-uninformative, 224 parsimony-informative, 135 constant characters) with $\mathrm{CI}=0.617, \mathrm{RI}=0.891, \mathrm{RC}=$ $0.550, \mathrm{HI}=0.383$ and $\mathrm{TL}=523$. The $\beta$-tubulin dataset contained 471 characters $(0$ parsimony-uninformative, 142 parsimony-informative, 329 constant characters) with $\mathrm{CI}=0.698, \mathrm{RI}=0.901, \mathrm{RC}=0.629, \mathrm{HI}=0.302$, and $\mathrm{TL}=304$. The LSU dataset contained 848 characters ( 7 parsimony-uninformative, 74 parsimony-informative and 767 constant characters) with $\mathrm{CI}=0.652, \mathrm{RI}=0.885, \mathrm{RC}=0.577, \mathrm{HI}=0.348$ and $\mathrm{TL}$ $=128$. The tree statistics for the combined dataset were $\mathrm{CI}=0.487, \mathrm{RI}=0.854, \mathrm{RC}=$ $0.416, \mathrm{HI}=0.513, \mathrm{TL}=2148$ (TreeBase Accession No. S12358), and the partition homogeneity test (PHT) on the datasets produced a P-value of 0.01 .

The topology of the trees emerging from the ML and MP analyses were similar for the individual gene regions as well as in the combined analysis with regards to the clades representing species isolated in this study. However, clades representing genera occasionally collapsed in individual analyses. Fixed alleles could be identified in the datasets for the clades of the species identified in this study (Tables 2-4). Seven clades were identified in the MP and ML analyses representing Lasiodiplodia, Diplodia, Tiarosporella, Dothiorella, Spencermartinsia, Phaeobotryon and Botryosphaeria.

Isolates resided in four genera (Fig. 1). Isolates CMW36468, CMW36469 and CMW36470 (from healthy branches of $A$. karroo in Pretoria) formed a distinct clade 
together with other Diplodia species. Isolates CMW36477, CMW36478 and CMW36479 (from healthy A. karroo in Pretoria and Bloemfontein) formed a distinct clade with Tiarosporella species. Isolates from healthy branches of A. karroo in Pretoria (CMW36480 and CMW36481) grouped separately with Spencermartinsia species, while the clade containing species of Dothiorella included two sub-clades (isolates CMW36460, CMW36461 and CMW36462 from branches with die-back from Pretoria, and isolates CMW36463 and CMW36464 from healthy branches in Pretoria, respectively). There was considerable sequence variation in the four gene regions (ITS, TEF-1 $\alpha, \beta$-tubulin and LSU rDNA) among isolates representing the undescribed species and those of their sister species, which included an undescribed Dothiorella species (Van der Walt et al. 2008) from Acacia mellifera (Table 2), Dothiorella longicollis Pavlic, T.I. Burgess \& M.J. Wingf. (Table 3), and an undescribed Spencermartinsia species (Van der Walt et al. 2008) from Acacia erioloba (Table 4).

\section{Morphological characteristics}

Isolates were divided into five groups based on culture morphology, conidial shape and colour. The isolates in the fifth group corresponded to Tiarosporella in the DNA sequence comparisons and had white, raised aerial mycelium at the centers of the cultures with gray edges and undersides of the plates, and produced large hyaline conidia different from those of the other taxa. Isolates in the other four groups had dark gray or olivaceous colonies with aerial hyphae and dark conidia. Diplodia, Dothiorella and Spencermartinsia isolates could be distinguished by differences in growth and colour of the isolates. The isolates residing in Diplodia had gray mycelium with dark, regular edges and mostly aseptate conidia while those in Dothiorella had dark gray mycelium with irregular edges. The Spencermartinsia isolates were similar to the Dothiorella isolates and had similar conidia, but the colonies had regular edges. The species distinguished by phylogenetic inference could also be distinguished from other species in the respective genera based on differences in pycnidium shape and conidial size.

The use of $A$. karroo twigs on MEA to induce fruiting structures resulted in only anamorph states that were similar in characteristics between genera. The substantial overlap in these characters allowed only limited comparisons with 
herbarium specimens and previous descriptions. Differences in ascospore septation distinguish Spencermartinsia (2-celled ascospores with an apiculus at either end of the ascospore) and Dothiorella (1-septate ascospores and apiculi absent), but ascospores were not observed in this study.

\section{TAXONOMY}

The following are descriptions of new species based on morphology:

Tiarosporella urbis-rosarum Jami, Gryzenh., Slippers \& M.J. Wingf. sp. nov.-MB 564139

Fig. 2

Etymology: The name refers to the city Bloemfontein, popularly called 'The city of roses', where this species was first isolated.

No teleomorph produced. Pycnidia produced on Acacia karroo twigs on MEA in 6-10 weeks, solitary, globose, dark black (29 $\left.{ }^{\prime \cdots} \mathrm{m}\right)$, up to $200 \mu \mathrm{m}$ wide, immersed, unilocular, with long necks (4-9 mm); wall 5-7 cell layers thick, outer layers composed of dark-brown textura angularis, becoming thin-walled and hyaline towards the inner region. Conidiogenous cells holoblastic, hyaline, cylindrical, (5-) 5.5-9.5 (-11) x (3-) 3.2-4 (-5) $\mu \mathrm{m}$. Conidia ovoid, smooth with fine granular content, thin-walled, hyaline, aseptate, apices rounded, (21-) 23.5-29.5 (-34) x (8-) 9-10 (-11) $\mu \mathrm{m}$.

Colonies on MEA with appressed mycelial mats, pycnidia emerging after 2 months under near-ultraviolet light on A. karroo twigs. Mycelium gray, white at the centres, becoming dark gray at the regular edges, reverse dark gray to black. Growth at 5-35 ${ }^{\circ} \mathrm{C}$. Growth rate $14.4 \mathrm{~mm}$ per day at an optimal temperature of $25{ }^{\circ} \mathrm{C}$; covering the agar surface in a $90 \mathrm{~mm}$ diam. Petri dish after 6 days in the dark.

Specimens examined: South Africa, Free State Province, Bloemfontein, June 2008, M. Gryzenhout, from healthy wood section of Acacia karroo, holotype PREM 60698 resulting from inoculations of living isolate to A. karroo twigs, living cultures CMW 36477 = CBS 130405.

Additional specimens: South Africa, Free State Province, Bloemfontein, June 2008, M. Gryzenhout, from healthy wood section of Acacia karroo. Paratype PREM 60699 (living cultures CMW 36478 = CBS 130406). South Africa, Gauteng Province, 
Pretoria, June 2008, M. Gryzenhout \& F. Jami, from healthy wood section of Acacia karroo. Paratype PREM 606700 (living cultures CMW $36479=$ CBS 130407).

Notes: Eight species of this genus have been described (Dragan, 2003). DNA sequences of only Tiarosporella madreeya, T. tritici and T. graminis var. karroo are, however, available (Crous et al., 2006) and the DNA sequences of T. urbis-rosarum differ from these species. The sizes of conidia of T. urbis-rosarum are very similar to those of $T$. tritici (Crous et al., 2006), but conidia of $T$. urbis-rosarum are slightly smaller $(23.5-29.5 \times 9-10 \mu \mathrm{m})$ than those of $T$. tritici $(29-38 \times 12-17 \mu \mathrm{m})$.

Diplodia allocellula Jami, Gryzenh., Slippers \& M.J. Wingf. sp. nov.-MB 564140

Fig. 3

Etymology: The name refers to the variability in length of the conidiogenous cells in this fungus.

No teleomorph produced. Pycnidia immersed on MEA in 6-10 weeks, solitary, globose, chestnut, covered by hyphal hairs, up to $100 \mu \mathrm{m}$ diam, without necks. Conidiogenous cells holoblastic, smooth with fine granular contents, unicellular, cylindrical to sub-cylindrical, hyaline and truncate at base, (4-) 4.2-5 (-5.5) x (10.3-) 13.4-23.6 (-27.6) $\mu \mathrm{m}$. Conidia ovoid to ellipsoid, smooth with fine granular content, apices rounded and truncated at the base, thick-walled, aseptate, initially hyaline, becoming dark brown or sepia (13“'k), aseptate, (9-) 10-12.5 (-14.5) x (20-) 21.5-25 (30) $\mu \mathrm{m}$.

Colonies on MEA initially white turning gray from the middle of colonies within 5-7 d, aerial mycelium slightly fluffy, becoming dense, cottony with age, turning smoke gray to dark gray $\left(23^{\prime \prime \prime}\right.$ d) toward the edges after 7-9 days, reverse olivaceous-black $\left(33^{\cdots}{ }^{\prime \prime} \mathrm{m}\right)$ and with regular edges. Growth in culture from 5-35 ${ }^{\circ} \mathrm{C}$. Growth rate of $18.2 \mathrm{~mm}$ per day optimal at $25{ }^{\circ} \mathrm{C}$ and covering $90 \mathrm{~mm}$ diam. Petri dishes after 5 days in the dark.

Specimens examined: South Africa, Gauteng Province, Pretoria (George Storrar avenue, Fountain circle), Nov. 2009, M. Gryzenhout \& F. Jami, from branch of Acacia karroo showing die-back, holotype PREM 60701 resulting from inoculations of living isolates onto A. karroo twigs, living cultures CMW $36468=$ CBS 130408. 
Additional specimens: South Africa, Gauteng Province, Pretoria (George Storrar avenue, Fountain circle), Nov. 2009, M. Gryzenhout \& F. Jami, from branch of Acacia karroo showing die-back. Paratype PREM 60702 (living cultures CMW 36469= CBS 130409) and PREM 60703 (living cultures CMW 36470= CBS 130410).

Notes: Diplodia allocellula grouped with D. mutila (Fr.) Mont., D. rosulata Gure, Slippers \& Stenlid and D. africana Damm \& Crous as sister species in the phylogenetic analyses of other Diplodia species. Diplodia allocellula differ phylogenically from its closest Diplodia relatives and morphologically in its smaller conidia (10-12.5 x 21.5-25 $\mu \mathrm{m})$, compared to those of $D$. mutila (13.2-13.5 x 25.1$25.7 \mu \mathrm{m})$, D. rosulata $(11-17.5 \times 25-32 \mu \mathrm{m})$ and D. africana $(10-15 \times 25.5-33 \mu \mathrm{m})$. Diplodia rosulata has been found from seeds of Prunus africana in Ethiopia (Gure et al., 2005), D. mutila is known from diseased Vitis vinifera, Pyrus communis, Quercus suber and Malus pumila in Spain, Portugal and USA (Alves et al., 2004), while D. africana has been described from wounds on Prunus persica in South Africa (Western Cape Province) (Damm et al., 2007). In contrast, Diplodia allocellula was obtained from healthy A. karroo tissue in this study in Pretoria, South Africa.

Dothiorella dulcispinae Jami, Gryzenh., Slippers \& M.J. Wingf. sp. nov.-MB 564141

Fig. 4

Etymology: The name refers to the host, Acacia karroo (Sweet Thorn), dulcis=sweet and spina $=\mathrm{a}$ thorn .

No teleomorph produced. Pycnidia produced on Acacia karroo twigs on MEA after 2-4 weeks, solitary, globose, dark brown, up to $200 \mu \mathrm{m}$ wide, semi-immersed, unilocular, with a short necks $(100-300 \mu \mathrm{m})$; wall 6-8 cell layers thick, outer layers composed of dark-brown textura angularis, becoming thin-walled and hyaline toward the inner region. Conidiogenous cells 1-2 celled, holoblastic, hyaline, cylindrical, proliferating percurrently near the apex. Conidia ovoid, smooth with fine granular content, rounded apices, thick-walled, initially hyaline and aseptate, becoming dark brown or sepia (13“'k) and 1-septate, with 2 cells of unequal length, apices rounded, (6-) 7-10 (-11) x (14-) 16-22 (-24) $\mu \mathrm{m}$.

Colonies on MEA developing dense aerial mycelium with age, olivaceousgray $\left(23^{\prime \cdots}\right)$, surface pale olivaceous-gray $\left(21^{\prime \prime \prime}\right.$ i) to olivaceous black $\left(27^{\prime \prime \prime} \mathrm{m}\right)$, 
reverse olivaceous-black, umbonate with irregular zonation and lobate edges. Growth at $5-35{ }^{\circ} \mathrm{C}, 17.9 \mathrm{~mm}$ per day and optimal at $25{ }^{\circ} \mathrm{C}$, covering the surface of $90 \mathrm{~mm}$ diam. Petri dishes after 5 days in the dark.

Specimens examined: South Africa, Gauteng Province, Pretoria, Nov. 2009, F. Jami, from die-back wood section of Acacia karroo, holotype PREM 60706 resulting from inoculations of living isolates onto A. karroo twigs (living cultures CMW $36460=$ CBS 130413).

Additional specimens: South Africa, Gauteng Province, Pretoria, Nov. 2009, F. Jami, from die-back wood section of Acacia karroo, paratype PREM 60707 (living cultures CMW 36461= CBS 130414) and PREM 60708 (living cultures CMW $36462=$ CBS 130415).

Note: Based on phylogenetic analyses, isolates of Dothiorella dulcispinae are most closely related to those of a undescribed species of Dothiorella, which is known as an endophyte of $A$. mellifera in South Africa (Van der Walt et al., 2008). It differs from the latter species in the morphology of pycnidia, conidiogenous cells and conidia which are all smaller than those of the undescribed Dothiorella species.

Dothiorella brevicollis Jami, Gryzenh., Slippers \& M.J. Wingf. sp. nov.-MB 564142

Fig. 5

Etymology: The name refers to the fact that the pycnidia have short necks.

No teleomorph produced. Pycnidia, produced on Acacia karroo twigs on MEA after 2-4 weeks, brown (7`m), up to $200 \mu \mathrm{m}$ wide, semi-immersed, unilocular, globose with a short neck; wall 5-7 cell layers thick, outer layers composed of darkbrown textura angularis, becoming thin-walled and hyaline toward the inner region. Conidiogenous cells holoblastic, hyaline, cylindrical, (3-) 3.2-3.7 (-4) x (3-) 3.2-7.5 (9) $\mu \mathrm{m}$. Conidia ovoid, smooth with fine granular content, rounded apices, thickwalled, initially hyaline and aseptate, becoming dark brown and 1-septate, with 2 cells of equal length, apices rounded, (8-) 9-12 (-13) x (20-) 21.5-26 (-27) $\mu \mathrm{m}$.

Colonies on MEA appressed, pycnidia emerging after 9-10 d under nearultraviolet light. Mycelium olivaceous-gray (21’’b), surface pale olivaceous-gray to dark olivaceous-gray $\left(23^{\cdots \cdots} 1\right)$, reverse olivaceous-black $\left(29^{\cdots \cdots} \mathrm{m}\right)$ to iron grey $\left(29^{\cdots \cdots} \mathrm{k}\right)$, irregular edges. Growth observed from $5-35^{\circ} \mathrm{C}$, reaching $17.6 \mathrm{~mm}$ per day 
and optimal at $25^{\circ} \mathrm{C}$, covering the surface of a $90 \mathrm{~mm}$ diam. Petri dish after 6 days in the dark.

Specimens examined: South Africa, Gauteng Province, Pretoria, Nov. 2009, F. Jami, from healthy wood section Acacia karroo, holotype PREM 60704 resulting from inoculations of living isolates onto A. karroo twigs (living cultures CMW $36463=$ CBS 130411).

Additional specimens: South Africa, Gauteng Province, Pretoria, Nov. 2009, F. Jami, from healthy wood section Acacia karroo, paratype PREM 60705 (living cultures CMW 36464= CBS 130412).

Notes: Do. brevicollis has shorter pycnidial necks than those of Do. longicollis. It can also be distinguished from Do. dulcispinae described in this study based on phylogenetic analyses and by its larger conidia.

Spencermartinsia pretoriensis Jami, Gryzenh., Slippers \& M.J. Wingf. sp. nov.-MB 564143

Fig. 6

Etymology: The name refers to Pretoria, where samples yielding the species were collected.

No teleomorph produced. Pycnidia produced on Acacia karroo twigs on MEA after 2-4 weeks, brown, up to $200 \mu \mathrm{m}$ wide, semi-immersed, unilocular, with short necks; wall 5-7 cell layers thick, outer layers composed of dark-brown textura angularis, becoming thin-walled and hyaline towards the inner regions. Conidiophores absent and reduced to conidiogenous cells, 1-2 celled, hyaline, holoblastic, cylindrical, proliferating percurrently near the apex, (3-) 3.2-7.5 (-9) x (3) 3.2-3.7 (-4) $\mu \mathrm{m}$. Conidia ovoid, smooth with a fine granular content, rounded apices, thick-walled, initially hyaline and aseptate, becoming dark brown ( 7 `m) and 1septate, with 2 cells of equal length, apices rounded, (18-) 20-28 (-33) x (6.5-) 7-14 (11) $\mu \mathrm{m}$.

Colonies on MEA appressed, and pycnidia emerging after 8-10 days. Mycelium pale olivaceous, surface pale olivaceous to dark greenish olivaceous, reverse olivaceous-black $\left(29^{\prime \prime \prime} \mathrm{m}\right)$, regular zonation and lobate edges. Growth from $5-35^{\circ} \mathrm{C}$; up to $22.5 \mathrm{~mm}$ per day and optimal at $25^{\circ} \mathrm{C}$, covering the surface of $90 \mathrm{~mm}$ diam. Petri dish after 4 days in the dark. 
Specimens examined: South Africa, Gauteng Province, Nov. 2009, F. Jami, from die-back wood section Acacia karroo, holotype PREM 60709 resulting from inoculations of living isolates onto A. karroo twigs (living cultures CMW 36480= CBS 130404)

Additional specimens: South Africa, Gauteng Province, Nov. 2009, F. Jami, from die-back wood section Acacia karroo, paratype PREM 60710 (living cultures CMW 36481= CBS 130405).

Note: Spencermartinsia pretoriensis is not distinguishable from an undesrcibed Spencermartinsia species from Acacia erioloba based on morphology and could be differentiated from this species only with DNA sequence comparisons (Table 4).

\section{DISCUSSION}

Extensive sampling for the Botryosphaeriaceae on native trees has been undertaken in South Africa in recent years. Despite this fact, this study yielded a large number of new taxa, which suggests that many undescribed species remain to be isolated and identified. Here we considered only tree species (A. karroo), in two areas where were not previously sampled. In the process we discovered five new species in four genera of the Botryosphaeriaceae. Identifications of the species collected were primarily based on DNA sequence comparisons of four loci. It was not possible to compare the species with the plethora of those previously described in these genera and for which no sequence data are available. However, morphological data were useful to distinguish these five species from each other and from other species described from the region.

Three of the five newly discovered species are relatively closely related and reside in the Spencermartinsia and Dothiorella clades. These two genera have only recently been split and were previously treated in the single genus Dothiorella. When Do. viticola was described as a new species, it could not be distinguished from $D o$. iberica and Do. sarmentorum based on anamorphic features, thus differences in teleomorph characters were used to differentiate the three species (Luque et al., 2005) where Do. viticola has 2-celled ascospores with apiculi at either end. Later studies introduced Do. viticola as the new genus Spencermartinsia (Phillips et al., 2008). The 
teleomorph for other members of Spencermartinsia spp. is still unknown, and their placement in the genus rests only on gene sequence similarities. In this study $S$. pretoriensis was placed in the genus because of its grouping with other Spencermartinsia spp. based on DNA sequences alone, and separate from the clade containing Dothiorella spp. These analyses, however, also show distinct clades within both the Dothiorella and Spencermartinsia clades, which might later be interpreted as representing distinct genera. As in the case of Dothiorella and Spencermartinsia, discovery of a teleomorph may also lead to changes in the taxonomy of this group.

Spencermartinsia species appear to be diverse on Acacia in southern Africa and the discovery of $S$. pretoriensis on A. karroo in this study adds to this view. All four Spencermartinsia spp. that are currently known were recently isolated from native Acacia spp. in southern Africa, such as A. erioloba, A. mellifera and A. tortillis (Van der Walt et al., 2008). Spencermartinsia viticola, the type species of the genus, was described from grape vines in Spain (Luque et al., 2005) and from citrus in California (Adesemoye and Eskalen, 2011). It was also found on A. melifera in Pretoria, South Africa (Van der Walt et al., 2008). Interestingly it is the only species thusfar known from hosts other than Acacia and from the countries other than South Africa. Further studies of the Botryosphaeriaceae on native Acacia will test the emerging hypothesis that this group evolved on this host and in Africa.

Tiarosporella spp. have a distinct culture and conidial morphology compared to other genera of the Botryosphaeriaceae. Species have a woolly mycelium that is white at the center and gray at the colony edges. Pycnidia have long necks and produce ovoid hyaline conidia. Three species, T. tritici B. Sutton \& Marasas from Triticum aestiuum (Poaceae), T. graminis var. karroo B. Sutton \& Marasas, and T. graminis var. gamines (Piroz. \& Shoemaker) Nag Raj from Tribulus terrestris (Zygophyllaceae), Eriocephalus sp. (Asteraceae) and Nestlera sp. (Poaceae) have been described from Heilbron (Free State province) and Middelburg (Eastern Cape province) in South Africa (Sutton \& Marasas, 1976). Crous et al. (2006) found that Tiarosporella grouped in an unresolved clade with Lasiodiplodia/Diplodia. Subsequent studies using greater numbers of samples showed that Diplodia and Lasiodiplodia group closely together (Phillips et al., 2008), but the placement of Tiarosporella was not addressed. Results of this study support the distinct grouping of Tiarosporella from species of Lasiodiplodia and Diplodia. 
Species of the Botryosphaeriaceae are well-known as latent pathogens that can cause disease under conditions of stress (Slippers \& Wingfield, 2007). Two of the five species described in this study (Dothiorella dulcispinae and Spencermartinsia pretoriensis) were isolated from diseased tissue, while three (Dothiorella brevicollis, Tiarosporella urbis-rosarum and Diplodia allocellula) were associated only with healthy A. karroo tissue. These patterns of isolation do not allow for deductions to be made regarding the ability of the fungi to cause disease on $A$. karroo, and pathogenicity trials will be needed to better understand the role of these fungi as possible disease agents.

The host ranges of the new species described in this study are unknown. Very few Botryosphaeriaceae appear to be host specific when they are sampled widely. For example, N. eucalyptorum (Crous, H. Smith \& M.J. Wingf.) Crous, Slippers \& A.J.L. Phillips and N. eucalypticola (Slippers, Crous \& M.J. Wingf.) Crous, Slippers \& A.J.L. Phillips were thought to be specific to Eucalyptus spp. (Slippers et al., 2004), but $N$. eucalyptorum was subsequently found on other Myrtaceae (Pérez et al., 2009). A number of species in the Botryosphaeriaceae such as L. theobromae, B. dothidea, and N. parvum are known to have wide host ranges (Slippers \& Wingfield, 2007). Similarly, of the 12 Botryosphaeriaceae species isolated by Van der Walt et al. (2008) from Acacia, three species (B. dothidea and undescribed species in Spencermartinsia and Pheaobotryon) were found on A. karroo and other Acacia species. It is thus expected that the species described here may also be found on other members of Acacia and perhaps even other tree genera.

A number of apparently host specific specific species are found among Dothiorella species, such as Do. moneti K. Taylor, Barber \& T.I. Burgess from Acacia rostellifera, Do. santali K. Taylor, Barber \& T.I. Burgess from Santalum acuminatum in Western Australia (Taylor et al., 2009), an undescribed species of Dothiorella from A. melifera in South Africa (Van der Walt et al., 2008), and Do. casuarini J. de Wet, Slippers \& M.J. Wingf. from a Casuarina sp. in Australia (De Wet et al., 2009). However, very few Botryosphaeriaceae appear to be host specific when they are sampled widely. For example, N. eucalyptorum (Crous, H. Smith \& M.J. Wingf.) Crous, Slippers \& A.J.L. Phillips and N. eucalypticola (Slippers, Crous \& M.J. Wingf.) Crous, Slippers \& A.J.L. Phillips were thought to be specific to Eucalyptus spp. (Slippers et al., 2004), but N. eucalyptorum was subsequently found 
on other Myrtaceae (Pérez et al., 2009). Other species in Dothiorella have been reported from different hosts such as Do. longicollis Pavlic, Burgess \& M.J. Wingf. described from both Lysiphyllum cunninghamii and a Terminalia sp. in Western Australia (Pavlic et al., 2008), Do. sarmentorum from Malus, Ulmus, Pyrus, Prunus, Menispermum and almond, and Do. iberica from Quercus and Malus in Europe and USA (Inderbitzin et al., 2010; Phillips et al., 2005). A number of species in the Botryosphaeriaceae such as L. theobromae, B. dothidea, and N. parvum are also known to have wide host ranges (Slippers \& Wingfield, 2007). Similarly on Acacia, of the 12 Botryosphaeriaceae species isolated by Van der Walt et al. (2008) from Acacia, three species (B. dothidea and undescribed species in Spencermartinsia and Pheaobotryon) were found on A. karroo and other Acacia species. It is thus expected that the species described here may also be found on other members of Acacia and perhaps even other tree genera and their complete host ranges of the new species described in this study are still unknown.

The two different areas sampled in this study revealed different Botryosphaeriaceae species. Only one of five species was found in Bloemfontein, while all five occurred in Pretoria. Van der Walt et al. (2008) found that geography influenced the structure of Botryosphaeriaceae diversity on Acacia. In that study, which included samples from diverse areas of southern Africa, only three of 12 species overlapped among the regions sampled, while the others were found at only one or two sites. Other studies on the Botryosphaeriaceae have shown similar patterns. For example, seven species Botryosphaeriaceae from Adansonia gibbosa sampled at five different sites in Western Australia (Pavlic et al., 2008), and six Botryosphaeriaceae species from Prunus dulcis from seven different sites in California, USA (Inderbitzin et al., 2010) revealed largely different species at the different sites. Thorough and repeated sampling targeting the various Botryosphaeriaceae species on Acacia karroo will, however, be needed to delimit geographic boundaries for the various species on this host.

Recent studies on the Botryosphaeriaceae from diverse native trees in South Africa (Begoude et al., 2010; Mehl et al., 2011; Pavlic et al., 2007; Van der Walt et $a l ., 2008$ ) have resulted in the discovery of a large number of Botryosphaeriaceae species in this region. We, therefore, expected that the rate of new species descriptions in the family would decrease with additional sampling. The discovery of 
five new species in this study from a previously sampled host, and from only a few samples and sites, indicates that this expectation is unfounded and may not be realistic until a greater diversity of hosts have been sampled in many more locations across the region. A. karroo might be an ideal host, given its wide incidence across the region, to target for sampling alongside other hosts that are more geographically isolated. Such future work would provide a baseline of data on the geographical and host influence on structuring diversity in this important family of latent tree pathogens.

\section{ACKNOWLEDGEMENTS}

We thank Dr. Seonju Marincowitz for providing advice regarding microscopy, Roger Menard and Melodie Putnam for reviewing of the manuscript and Dr. Hugh F. Glen for providing the species names. Members of the Tree Protection Cooperative Programme (TPCP), the DST/NRF Centre of Excellence in Tree Health Biotechnology (CTHB) and the University of Pretoria, South Africa, are acknowledged for financial support.

\section{REFERENCES}

ADESEMOYE A. \& ESKALEN A., 2011 - First report of Spencermartinsia viticola, Neofusicoccum australe, and N. parvum causing branch canker of citrus in California. Plant Disease 95 (6): 770.

ALVES A., CORREIA A., LUQUE J. \& PHILlIPS A., 2004 - Botryosphaeria corticola sp. nov. on Quercus species, with notes and description of Botryosphaeria stevensii and its anamorph, Diplodia mutila. Mycologia 96 (3): 598-613.

BARNES R., FILER D. \& MILTON S., 1996 - Acacia karroo. Monograph and annotated bibliography. Tropical Forestry Papers, 32 p.

BEGOUDE B.A.D., SLIPPERS B., WINGFIELD M.J. \& ROUX J., 2010 Botryosphaeriaceae associated with Terminalia catappa in Cameroon, South Africa and Madagascar. Mycological Progress 9: 101-123.

BEGOUDE B.A.D., SLIPPERS B., WINGFIELD M.J. \& ROUX J., 2011 - The pathogenic potential of endophytic Botryosphaeriaceous fungi on Terminalia species in Cameroon. Forest Pathology 41: 281-292. 
CARBONE I. \& KOHN L.M., 1999 - A method for designing primer sets for speciation studies in filamentous ascomycetes. Mycologia 91:553-556.

CROUS P.W., SLIPPERS B., WINGFIELD M.J., RHEEDER J., MARASAS W.F.O., PHILIPS A.J.L., ALVES A., BURGESS T., BARBER P. \& GROENEWALD J.Z., 2006 - Phylogenetic lineages in the Botryosphaeriaceae. Studies in Mycology 55: 235-253.

DAMM U., CROUS P.W. \& FOURIE P.H., 2007 - Botryosphaeriaceae as potential pathogens of Prunus species in South Africa, with descriptions of Diplodia africana and Lasiodiplodia plurivora sp. nov. Mycologia 99 (5): 664-680.

DE WET J., SLIPPERS B., PREISIG O., WINGFIELD B.D., TSOPELAS P. \& WINGFIELD M.J., 2009 - Molecular and morphological characterization of Dothiorella casuarini sp. nov. and other Botryosphaeriaceae with diplodia-like conidia. Mycologia 101 (4): 503-511.

DENMAN S., CROUS P.W., GROENEWALD J.Z., SLIPPERS B., WINGFIELD B.D. \& WINGFIELD M.J., 2003 - Circumscription of Botryosphaeria species associated with Proteaceae based on morphology and DNA sequence data. Mycologia 95 (2): 294-307.

DRAGAN K., 2003 — Tiarosporella species: Distribution and significance. Glasnik Šumarskog Fakulteta 87: 9-23.

FARRIS J., KALLERSJO M., KLUGE A. \& BULT C., 1995 — Testing significance of incongruence. Cladistics 10: 315-319.

GARDES M. \& BRUNS T., 1993 — ITS primers with enhanced specificity for basidiomycetes-application to the identification of mycorrhizae and rusts. Molecular ecology 2, 113-118.

GLASS N.L. \& DONALDSON G.C., 1995 - Development of primer sets designed for use with the PCR to amplify conserved genes from filamentous ascomycetes. Applied and Environmental Microbiology. 61, 1323-1330.

GURE A., SLIPPERS B. \& STENLID J., 2005 - Seed-borne Botryosphaeria spp. from native Prunus and Podocarpus trees in Ethiopia, with a description of the anamorph Diplodia rosulata sp. nov. Mycological Research 109 (9): 10051014.

HANLIN R.T., 1990 - Illustrated Genera of Ascomycetes. APS Press, St Paul, MN U.S.A, $236 \mathrm{p}$. 
HILLIS D.M. \& HUELSENBECK J.P., 1992 - Signal, noise, and reliability in molecular phylogenetic analyses. Journal of Heredity 83: 189-195.

HUELSENBECK J.P., BULL J.J. \& CUNNINGHAM C.W., 1996 - Combining data in phylogenetic analysis. Trends in Ecology \& Evolution 11 (4): 152-158.

INDERBITZIN P., BOSTOCK R., TROUILLAS F.P. \& MICHAILIDES T.J., 2010 - A six-locus phylogeny reveals high levels of species diversity in Botryosphaeriaceae from California almond. Mycologia 102 (6): 1350-1368.

KATOH K., KUMA K., TOH H. \& MIYATA T., 2005 - MAFFT version 5: improvement in accuracy of multiple sequence alignment. Nucleic Acids Research 33 (2): 511.

LEE S. \& TAYLOR J., 1990 - Isolation of DNA from fungal mycelia and single spores. In: PCR protocols: a guide to methods and applications (Innis M.A., Gelfand D.H., Sninsky J.J., White T.J., eds), Academic Press, San Diego, Calif.

LU G. \& MORIYAMA E.N., 2004 - Vector NTI, a balanced all-in-one sequence analysis suite. Briefings in Bioinformatics 5 (4): 378-388.

LUQUE J., MARTOS S. \& PHILLIPS A.J.L., 2005 - Botryosphaeria viticola sp. nov. on grapevines: a new species with a Dothiorella anamorph. Mycologia 97 (5): 1111-1121.

MEHL J.W.M., SLIPPERS B., ROUX J. \& WINGFIELD M.J., 2011 Botryosphaeriaceae associated with Pterocarpus angolensis (kiaat) in South Africa. Mycologia 103(3): 534-553.

PAVLIC D., SLIPPERS B., COUTINHO T.A., GRYZENHOUT M. \& WINGFIELD M.J., 2004 - Lasiodiplodia gonubiensis sp. nov., a new Botryosphaeria anamorph from native Syzygium cordatum in South Africa. Studies in Mycology 50: 313-322.

PAVLIC D., SLIPPERS B., COUTINHO T.A. \& WINGFIELD M.J., 2007 Botryosphaeriaceae occurring on native Syzygium cordatum in South Africa and their potential threat to Eucalyptus. Plant Pathology 56 (4): 624-636.

PAVLIC D., WINGFIELD M.J., BARBER P., SLIPPERS B., HARDY G. \& BURGESS T.I., 2008 - Seven new species of the Botryosphaeriaceae from baobab and other native trees in Western Australia. Mycologia 100 (6): 851866. 
PÉREZ C.A., WINGFIELD M.J., SLIPPERS B., ALTIER N.A. \& BLANCHETTE R.A., 2009 - Neofusicoccum eucalyptorum, a Eucalyptus pathogen, on native Myrtaceae in Uruguay. Plant Pathology 58 (5): 964-970.

PHILLIPS A., ALVES A., CORREIA A. \& LUQUE J., 2005 - Two new species of Botryosphaeria with brown, 1-septate ascospores and Dothiorella anamorphs. Mycologia 97 (2): 513-529.

PHILLIPS A.J.L., ALVES A., PENNYCOOK S.R., JOHNSTON P.R., RAMALEY A., AKULOV A. \& CROUS P.W., 2008 - Resolving the phylogenetic and taxonomic status of dark-spored teleomorph genera in the Botryosphaeriaceae. Persoonia 21: 29-55.

POSADA D. \& BUCKLEY T. R., 2004 - Model selection and model averaging in phylogenetics: advantages of the AIC and Bayesian approaches over likelihood ratio tests. Systematic Biology 53: 793-808.

ROUX J. \& WINGFIELD M.J., 1997 - Survey and virulence of fungi occurring on diseased Acacia mearnsii in South Africa. Forest Ecology and Management 99 (3): 327-336.

ROUX J., WINGFIELD M.J. \& MORRIS M.J., 1997 — Botryosphaeria dothidea as a pathogen of Acacia mearnsii in South Africa. South African Journal of Science 99: 327-336.

RAYNER R.W., 1970 - A mycological colour chart. Kew, Surrey, UK: CMI and British Mycological Society.

SLIPPERS B., FOURIE G., CROUS P.W., COUTINHO T.A., WINGFIELD B.D., CARNEGIE A.J. \& WINGFIELD M.J., 2004 - Speciation and distribution of Botryosphaeria spp. on native and introduced Eucalyptus trees in Australia and South Africa. Studies in Mycology 50: 343-358.

SLIPPERS B. \& WINGFIELD M.J., 2007 - Botryosphaeriaceae as endophytes and latent pathogens of woody plants: diversity, ecology and impact. Fungal Biology Reviews 21 (2-3): 90-106.

SMITH H., CROUS P.W., WINGFIELD M.J., COUTINHO T.A. \& WINGFIELD B.D., 2001 - Botryosphaeria eucalyptorum sp. nov., a new species in the $B$. dothidea complex on Eucalyptus in South Africa. Mycologia 93 (2): 277-285. 
SMITH H., KEMP G.H.J. \& WINGFIELD M.J., 1994 - Canker and die-back of Eucalyptus in South Africa caused by Botryosphaeria dothidea. Plant Pathology 43: 1031-1034.

SUTTON B. \& MARASAS W., 1976 - Observations on Neottiosporina and Tiarosporella. Transactions of the British Mycological Society 67 (1): 69-76.

SWART W.J. \& WINGFIELD M.J., 1991 - Biology and control of Sphaeropsis sapinea on Pinus species in South Africa. Plant Disease 75: 761-766.

SWOFFORD D.L., 2001 - PAUP. Phylogenetic analysis using parsimony (and other methods). Version 4. Sunderland, MA, USA: Sinaur Associates.

TAYLOR K., BARBER P.A., ST. J. HARDY G.E. \& BURGESS T.I., 2009 Botryosphaeriaceae from tuart (Eucalyptus gomphocephala) woodland, including descriptions of four new species. Mycological Research 113 (3): $337-353$

TIMBERLAKE J., FAGG C. \& BARNES R.D., 1999 — Field Guide to the acacias of Zimbabwe. CBC Publishing, Harare, 160 p.

VAN DER WALT F.J.J., MARAIS G.J., ROUX J., WINGFIELD M.J. \& SLIPPERS B., 2008 - Botrosphaeriaceae associated with Acacia species in southern Africa with special reference to Acacia melifera. Masters Thesis, University of Pretoria: South Africa, 198 p.

VAN NIEKERK J.M., CROUS P.W., GROENEWALD J.Z., FOURIE P.H. \& HALLEEN F., 2004 — DNA phylogeny, morphology and pathogenicity of Botryosphaeria species on grapevines. Mycologia 96 (4): 781-798.

VILGALYS R. \& HESTER M., 1990 - Rapid genetic identification and mapping of enzymatically amplified ribosomal DNA from several Cryptococcus spp. Journal of Bacteriology, 172, 4238-4246.

WHITE T.J., BRUNS T., LEE S. \& TAYLOR J., 1990 - Amplification and direct sequencing of fungal ribosomal RNA genes for phylogenetics. In: PCR Protocols: A Guide to Methods and Applications. Ed. by Innis, M.A.; Gelfand, D.H.; Snisky, J.J.; White, T.J.; San Diego, CA, USA: Academic Press, pp. $315-22$. 
Fig. 1. ML tree of the combined data set of ITS ribosomal DNA, TEF-1 $\alpha, \beta$-tubulin and LSU gene region sequences. Bootstrap values for ML (roman) and MP (italic) above $60 \%$ are given at the nodes. The numbers are shown in bold for isolates newly sequenced in this study. The tree was rooted to Pseudofusicoccum stromaticum (CBS117448 and CBS117449).

Fig. 2. Micrographs of Tiarosporella urbis-rosarum. 1) Culture morphology on MEA (scale bar $=100 \mu)$, 2) Pycnidium, 3) Conidia (scale bar $=10 \mu \mathrm{m})$, 4-6) Conidiogenous cells (scale bar 4,5 =10 $\mu \mathrm{m} \&$ scale bar $6=5 \mu \mathrm{m}$ ).

Fig. 3. Micrographs of Diplodia allocellula 1) Culture morphology on MEA, 2) Pycnidium (scale bar $=100 \mu), 3)$ Conidiogenous cells $($ scale bar $=10 \mu \mathrm{m}), 4)$ Germinating conidia (scale bar $=10 \mu \mathrm{m}$ ), 5) Young conidia with attached conidiogenous cells (scale bar $=5 \mu \mathrm{m}, 6$ ) Maturing conidia at various stages (scale $\operatorname{bar}=10 \mu \mathrm{m})$.

Fig. 4. Micrographs of Dothiorella dulcispinae. 1) Culture morphology on MEA, 2) Longitudinal section through pycnidium (scale bar $=100 \mu \mathrm{m}), 3,4)$ Conidiogenous cells (scale bar $=10 \mu \mathrm{m}), 5)$ Young conidia (scale bar $=5 \mu \mathrm{m}), 6$ ) Conidia at various stages of maturity (scale bar $=10 \mu \mathrm{m})$.

Fig. 5. Micrographs of Dothiorella brevicollis. 1) Culture morphology on MEA, 2) Pycnidium (scale bar $=100 \mu \mathrm{m}$ ), 3) Longitudinal section through pycnidium (scale bar $=100 \mu \mathrm{m}), 4-6)$ Conidia and conidiogenous cells (scale bar $=10 \mu \mathrm{m}), 7,8)$ Conidia (scale bar $=10 \mu \mathrm{m}), 9)$ Chlamydospore $($ scale bar $=10 \mu \mathrm{m})$.

Fig. 6. Micrographs of Spencermartinsia pretoriensis. 1) Culture morphology on MEA, 2) Longitudinal section through pycnidium (scale bar $=100 \mu \mathrm{m}$ ), 3,4) Conidiogenous cells (scale bar $=20 \mu \mathrm{m}), 5,6)$ Conidia (scale bar $=10 \mu \mathrm{m})$. 
Table 1. Representative isolates from Acacia karroo used in the phylogenetic analyses.

\begin{tabular}{|c|c|c|c|c|c|c|c|}
\hline \multirow[t]{2}{*}{ Isolate No. } & \multirow[t]{2}{*}{ Identity } & \multirow[t]{2}{*}{ Location } & \multirow[t]{2}{*}{ Collector } & \multicolumn{4}{|c|}{ GenBank } \\
\hline & & & & ITS & EF1- $\alpha$ & LSU & $\beta$-tubulin \\
\hline CMW36477 & Tiarosporella urbis-rosarum & Bloemfontein, South Africa & M. Gryzenhout & JQ239407 & JQ239394 & JQ239420 & JQ239381 \\
\hline CMW36478 & T. urbis-rosarum & Bloemfontein, South Africa & M. Gryzenhout & JQ239408 & JQ239395 & JQ239421 & JQ239382 \\
\hline CMW36479 & T. urbis-rosarum & Pretoria, South Africa & F. Jami \& M. Gryzenhout & JQ239409 & JQ239396 & JQ239422 & JQ239383 \\
\hline CMW36468 & Diplodia allocellula & Pretoria, South Africa & F. Jami \& M. Gryzenhout & JQ239397 & JQ239384 & JQ239410 & JQ239378 \\
\hline CMW36469 & D. allocellula & Pretoria, South Africa & F. Jami \& M. Gryzenhout & JQ239398 & JQ239385 & JQ239411 & JQ239379 \\
\hline CMW36470 & D. allocellula & Pretoria, South Africa & F. Jami \& M. Gryzenhout & JQ239399 & JQ239386 & JQ239412 & JQ239380 \\
\hline CMW36460 & Dothiorella dulcispinae & Pretoria, South Africa & F. Jami \& M. Gryzenhout & JQ239400 & JQ239387 & JQ239413 & JQ239373 \\
\hline CMW36461 & Do. dulcispinae & Pretoria, South Africa & F. Jami \& M. Gryzenhout & JQ239401 & JQ239388 & JQ239414 & JQ239374 \\
\hline CMW36462 & Do. dulcispinae & Pretoria, South Africa & F. Jami \& M. Gryzenhout & JQ239402 & JQ239389 & JQ239415 & JQ239375 \\
\hline CMW36463 & Do. brevicollis & Pretoria, South Africa & F. Jami \& M. Gryzenhout & JQ239403 & JQ239390 & JQ239416 & JQ239371 \\
\hline CMW36464 & Do. brevicollis & Pretoria, South Africa & F. Jami \& M. Gryzenhout & JQ239404 & JQ239391 & JQ239417 & JQ239372 \\
\hline CMW36480 & Spencermartinsia pretoriensis & Pretoria, South Africa & F. Jami \& M. Gryzenhout & JQ239405 & JQ239392 & JQ239418 & JQ239376 \\
\hline CMW36481 & S. pretoriensis & Pretoria, South Africa & F. Jami \& M. Gryzenhout & JQ239406 & JQ239393 & JQ239419 & JQ239377 \\
\hline
\end{tabular}


Table 2. Polymorphic nucleotides fixed between an undescribed Dothiorella species from Acacia mellifera and Dothiorella dulcispinae based on sequence data of the ITS, TEF-1 $\alpha$, LSU and $\beta$-tubulin. Polymorphisms unique to Dothiorella dulcispinae are highlighted.

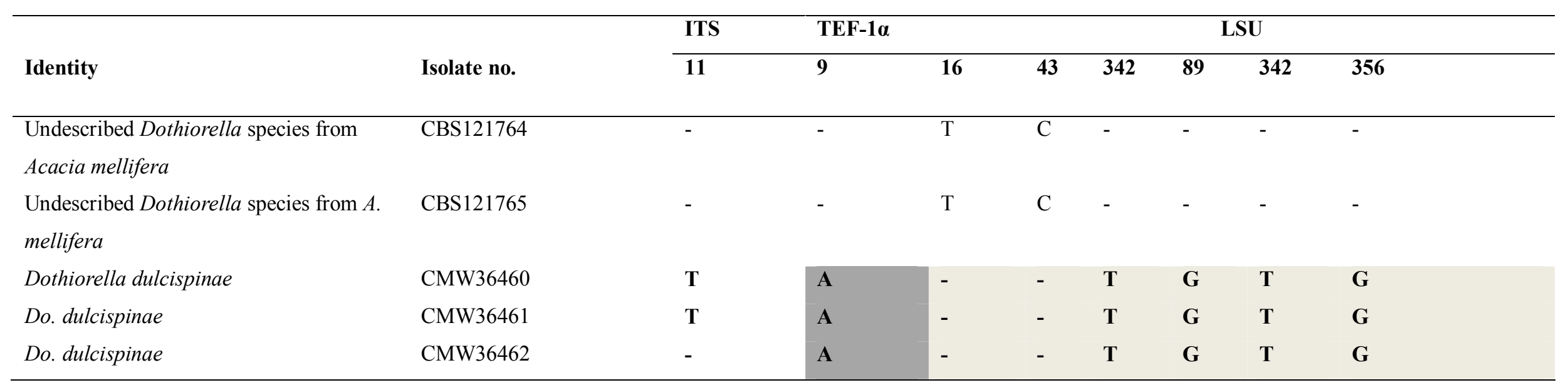

\begin{tabular}{|c|c|c|c|c|c|c|c|c|c|c|c|c|c|c|c|}
\hline \multirow[b]{2}{*}{ Identity } & \multirow[b]{2}{*}{ Isolate no. } & \multicolumn{14}{|c|}{$\beta$-tubulin } \\
\hline & & 43 & 49 & 56 & 61 & 139 & 157 & 166 & 171 & 180 & 267 & 333 & 345 & 348 & 410 \\
\hline $\begin{array}{l}\text { Undescribed Dothiorella species } \\
\text { from Acacia mellifera }\end{array}$ & CBS121764 & $\mathrm{T}$ & $\mathrm{A}$ & $\mathrm{A}$ & - & $\mathrm{G}$ & $\mathrm{C}$ & - & $\mathrm{C}$ & $\mathrm{C}$ & $\mathrm{A}$ & $\mathrm{G}$ & $\mathrm{T}$ & $\mathrm{T}$ & - \\
\hline $\begin{array}{l}\text { Undescribed Dothiorella species } \\
\text { from } A \text {. mellifera }\end{array}$ & CBS121765 & $\mathrm{T}$ & A & $\mathrm{A}$ & - & G & $\mathrm{C}$ & - & $\mathrm{C}$ & $\mathrm{C}$ & $\mathrm{A}$ & G & $\mathrm{T}$ & $\mathrm{T}$ & - \\
\hline Dothiorella dulcispinae & CMW36460 & - & - & - & $\mathbf{T}$ & - & - & $\mathbf{C}$ & G & $\mathbf{T}$ & G & - & - & - & $\mathbf{C}$ \\
\hline Do. dulcispinae & CMW36461 & - & - & - & $\mathbf{T}$ & - & - & $\mathbf{C}$ & $\mathbf{G}$ & $\mathbf{T}$ & $\mathbf{G}$ & - & - & - & $\mathbf{C}$ \\
\hline Do. dulcispinae & CMW36462 & - & - & - & $\mathbf{T}$ & - & - & C & $\mathbf{G}$ & $\mathbf{T}$ & $\mathbf{G}$ & - & - & - & C \\
\hline
\end{tabular}


Table 3. Polymorphic nucleotides from sequence data of the ITS, TEF-1 $\alpha$, LSU and $\beta$-tubulin to show the relationships between Dothiorella longicollis and Dothiorella brevicollis. Polymorphisms unique to Dothiorella brevicollis are highlighted. (There were no differences for LSU sequence data.)

\begin{tabular}{|c|c|c|c|c|c|c|c|c|c|c|c|c|}
\hline \multirow[b]{2}{*}{ Identity } & \multirow[b]{2}{*}{ Isolate no. } & \multicolumn{5}{|c|}{ ITS } & \multicolumn{4}{|c|}{ 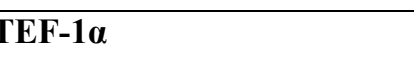 } & \multicolumn{2}{|c|}{$\beta$-tubulin } \\
\hline & & 72 & 9 & 31 & 39 & 88 & 90 & 244 & 247 & 350 & 56 & 450 \\
\hline Dothiorella longicollis & CBS122066 & $\mathbf{T}$ & $\mathrm{A}$ & $\mathbf{A}$ & $\mathbf{T}$ & $\mathbf{T}$ & - & - & $\mathbf{A}$ & $\mathrm{C}$ & - & $\mathbf{T}$ \\
\hline Do. longicollis & CMW26164 & $\mathbf{T}$ & A & $\mathbf{A}$ & $\mathbf{T}$ & $\mathbf{T}$ & - & - & $\mathbf{A}$ & $\mathrm{C}$ & - & $\mathbf{T}$ \\
\hline Dothiorella brevicollis & CMW36463 & - & G & - & - & - & G & $\mathbf{A}$ & - & - & $\mathbf{A}$ & - \\
\hline Do. brevicollis & CMW36464 & - & $\mathbf{G}$ & - & - & - & G & $\mathbf{A}$ & - & - & $\mathbf{A}$ & - \\
\hline
\end{tabular}


Table 4. Polymorphic nucleotides from sequence data of the ITS, TEF-1 $\alpha$, LSU and $\beta$-tubulin showing the relationships between an undescribed Spencermartinsia species from Acacia erioloba and Spencermartinsia pretoriensis. Polymorphisms unique to Spencermartinsia pretoriensis are highlighted.

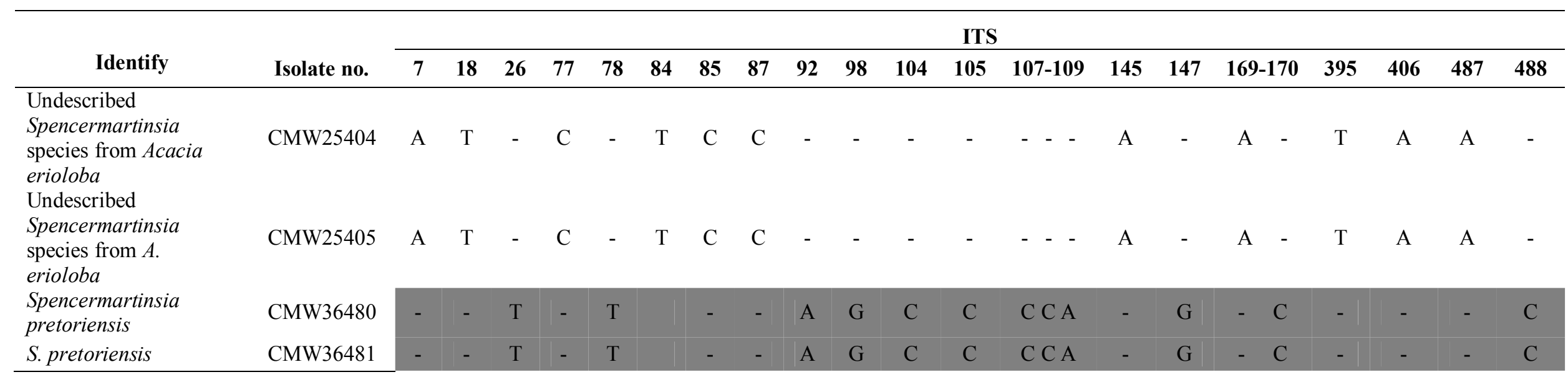

\begin{tabular}{|c|c|c|c|c|c|c|c|c|c|c|c|c|c|c|c|c|c|c|c|c|c|c|c|c|c|}
\hline \multirow[b]{2}{*}{ Identify } & \multirow[b]{2}{*}{ Isolate no. } & \multicolumn{24}{|c|}{ TEF-1 $\alpha$} \\
\hline & & 8 & 20 & 21 & 34 & 36 & 37 & 40 & 46 & 47 & 48 & 59 & 128 & 155 & 160 & 161 & 163 & 164 & 166 & 180 & 193 & 216 & 220 & 244 & 247 \\
\hline $\begin{array}{l}\text { Undescribed } \\
\text { Spencermartinsia } \\
\text { species from } \\
\text { Acacia erioloba }\end{array}$ & CMW25404 & $\mathrm{T}$ & $\mathrm{G}$ & $\mathrm{C}$ & $\mathrm{T}$ & $\mathrm{T}$ & $\mathrm{C}$ & $\mathrm{T}$ & $\mathrm{T}$ & $\mathrm{C}$ & $\mathrm{A}$ & $\mathrm{T}$ & - & A & $\mathrm{C}$ & A & $\mathrm{C}$ & $\mathrm{C}$ & $\mathrm{C}$ & - & A & $\mathrm{C}$ & A & A & $\mathrm{A}$ \\
\hline $\begin{array}{l}\text { Undescribed } \\
\text { Spencermartinsia } \\
\text { species from } A \text {. } \\
\text { erioloba }\end{array}$ & CMW25405 & $\mathrm{T}$ & $\mathrm{G}$ & $\mathrm{C}$ & $\mathrm{T}$ & $\mathrm{T}$ & $\mathrm{C}$ & $\mathrm{T}$ & & $\mathrm{C}$ & $\mathrm{A}$ & $\mathrm{T}$ & - & A & $\mathrm{C}$ & A & $\mathrm{C}$ & $\mathrm{C}$ & $\mathrm{C}$ & - & A & $\mathrm{C}$ & A & A & $\mathrm{A}$ \\
\hline $\begin{array}{l}\text { Spencermartinsia } \\
\text { pretoriensis }\end{array}$ & CMW36480 & $\mathrm{C}$ & $\mathrm{C}$ & G & - & $\mathrm{C}$ & - & $\mathrm{C}$ & $\mathrm{C}$ & $\mathrm{G}$ & $\mathrm{T}$ & - & $\mathrm{C}$ & $\mathrm{G}$ & G & G & $\mathrm{T}$ & - & $\mathrm{T}$ & A & $\mathrm{T}$ & $\mathrm{G}$ & $\mathrm{C}$ & G & $\mathrm{C}$ \\
\hline
\end{tabular}




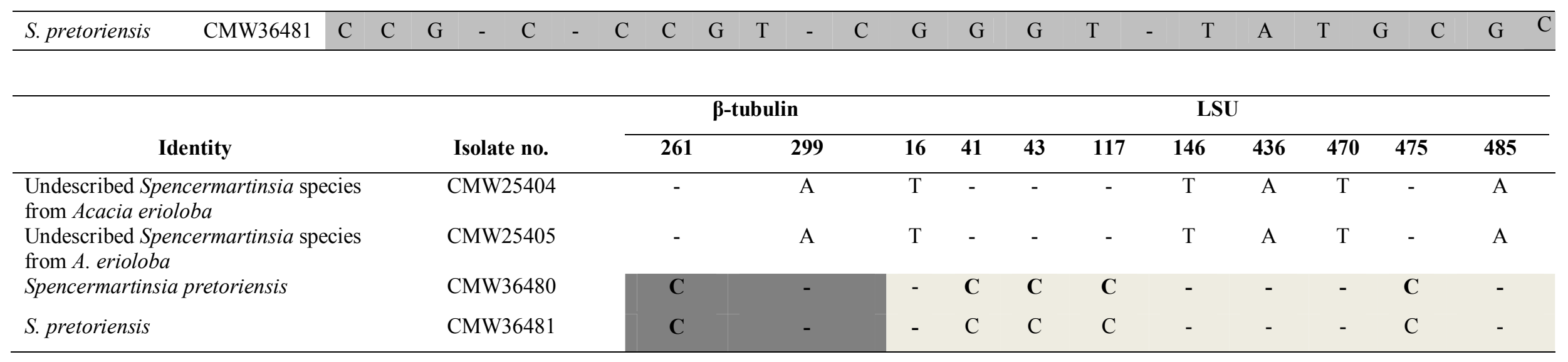

